\title{
The First Synthesis of ( \pm )-3,4-Dihydroxy-8,9-methylenedioxypterocarpan, an Antitumoral Agent and its Coumestan Derivative
}

\author{
Alcides J. M. da Silva, Chaquip D. Netto and Paulo R. R. Costa* \\ Núcleo de Pesquisas de Produtos Naturais, Centro de Ciências da Saúde, Bloco H, Universidade Federal do Rio de \\ Janeiro, 21.941-590 Rio de Janeiro - RJ, Brazil

\begin{abstract}
Apresentamos a primeira síntese do ( \pm )-3,4-diidroxi-8,9-metilenodioxipterocarpano, um isoflavonóide natural que apresenta atividade antitumoral. A etapa chave envolveu uma arilação de Heck entre o 7,8-dibenziloxicromeno e o organomercurial derivado do sesamol, seguido de reação de desbenzilação. $\mathrm{O}$ aduto de Heck foi também empregado na síntese do correspondente derivado cumestano, utilizando DDQ como agente oxidante.
\end{abstract}

We report the first synthesis of ( \pm )-3,4-dihydroxy-8,9-methylenedioxypterocarpan, a natural isoflavonoid that shows antitumoral activity. The key step involved the Heck reaction between the 7,8-dibenzyloxychromen and the organomercurial derived from sesamol, followed by debenzylation. The Heck adduct was also employed in the synthesis of the corresponding coumestan derivative, using DDQ as oxidant agent.

Keywords: isoflavonoids, pterocarpan, DDQ, antitumoral agents, coumestan

\section{Introduction}

A great number of naturally occurring biologically active flavonoids is described in the literature. In the area of antitumor drug discovery, some flavonoids derivatives ( chalcones, flavones, isoflavones, rotenoids etc. ) were shown to be active in vitro and in vivo. ${ }^{1}$ At the present time, cancer claims the lives of more than seven million people worldwide on an annual basis. Thus, the development of new cancer treating drugs is a must. ${ }^{2}$ In 1995, Wall et al. isolated three pterocarpans from Petalostemon purpureus (Figure 1). ${ }^{3}$ Compound (+)6aS, $11 \mathrm{a} S$-3,4-Dihydroxy-8,9-methylenedioxypterocarpan (1) was active in a standard in vitro DNA strand-scission assay, and presented cytotoxity toward $\mathrm{KB}$ tumor cell line $\left(\mathrm{ED}_{50}\right.$ $\left.=0.9 \mu \mathrm{g} \mathrm{mL}^{-1}\right)$. Pterocarpans (2) and maackiain (3) $[(+)-$ 6a $S, 11$ a $S$-4-hydroxy-3-methoxy-8,9-methylenedioxypterocarpan] were found to be moderately active for $\mathrm{KB}$ cells $\left(\mathrm{ED}_{50}\right.$ values of $4.0 \mu \mathrm{g} \mathrm{mL}^{-1}$ and $5.6 \mu \mathrm{g} \mathrm{mL}^{-1}$, respectively), but inactive in the DNA strand-scission assay. Since these compounds have the same pterocarpan skeleton and differ only in the pattern of substitution in ring A, we believe that the cathecol moiety in compound $\mathbf{1}$ is important for antitumoral activity. The enantiomers of $\mathbf{1} \mathrm{e}$

*e-mail: lqb@nppn.ufrj.br $\mathbf{2}$ were also previously isolated from plants, ${ }^{4}$ while $\mathbf{3}$ has been isolated only as a racemate. ${ }^{5}$

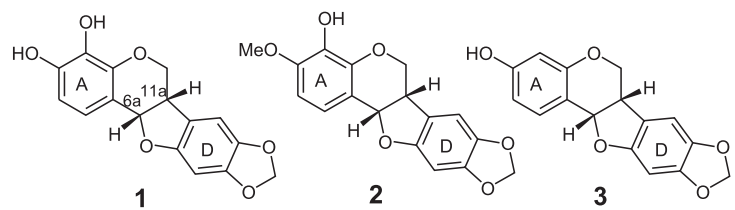

Figure 1. Natural pterocarpans.

As part of a program aimed at synthesizing biologically active anticancer products, ${ }^{6,7}$ we describe the first racemic synthesis of the natural product 3,4-dihydroxy-8,9methylenedioxypterocarpan (1) and its derivative, 3,4dihydroxy-8,9-methylenedioxycoumestan (13).

\section{Results and Discussion}

The key step ${ }^{6,7}$ in our strategy to prepare compound $\mathbf{1}$ was the coupling of chromen $\mathbf{8}$ and the organomercurial 9 derived from sesamol. ${ }^{8}$ The chromen was synthesized using 2,3-dimethoxybenzaldeyde (4) as starting material. Treatment of 4 with $\mathrm{BBr}_{3}$ at $-78{ }^{\circ} \mathrm{C}$ gave the cathecol derivative in an excellent yield. ${ }^{9}$ This compound was bisprotected with the benzyl group leading to aldeyde $\mathbf{5}$. The corresponding phenol $\mathbf{6}$ was prepared by Baeyer-Villiger 
oxidation using MCPBA. O-alkylation of the resulting phenol was acomplished by using 3-iodopropanal dimethylacetal, furnishing compound 7. Cyclization of 7 in acid medium led to chromen $\mathbf{8}$ in good yield (Scheme 1).

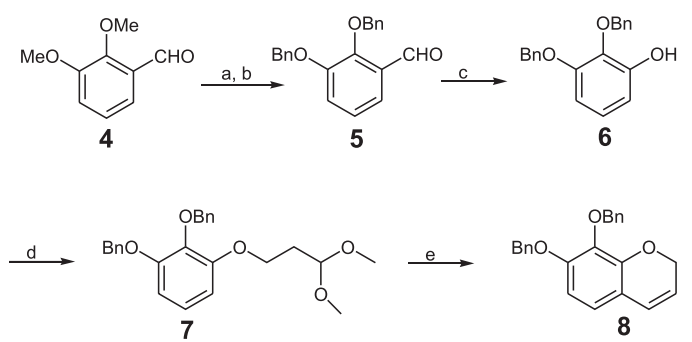

Scheme 1. Reagents and conditions: a) $\mathrm{BBr}_{3}, \mathrm{CH}_{2} \mathrm{Cl}_{2},-78{ }^{\circ} \mathrm{C}, 95 \%$; b) $\mathrm{BnCl}, \mathrm{K}_{2} \mathrm{CO}_{3}$, EtOH, Reflux, $60 \%$; c) $m \mathrm{CPBA}, \mathrm{CH}_{2} \mathrm{Cl}_{2}, 90 \%$; d) 3iodo propanal dimethylacetal, $\mathrm{KOH}$, THF, reflux; e) $20 \%$ aq. $\mathrm{HCl}$, THF, rt, 70\% (2 steps).

Compound $\mathbf{8}$ was allowed to react with 9 in the presence of lithium tetrachloropalladate II and acetone leading to cis-( \pm$)-\mathrm{O}-$ di-benzyl-pterocarpan $\mathbf{1 0} .^{10}$ Finally, natural product 1 was obtained by hydrogenolysis of the benzyl groups using the catalytic amount of Pd-C (10\% m/m) and all the spectroscopic data were similar to those observed in the natural product. ${ }^{3}$ We also observed the clevage of the furan ring when an excess of Pd-C was used, to yield product 11. (Scheme 2).

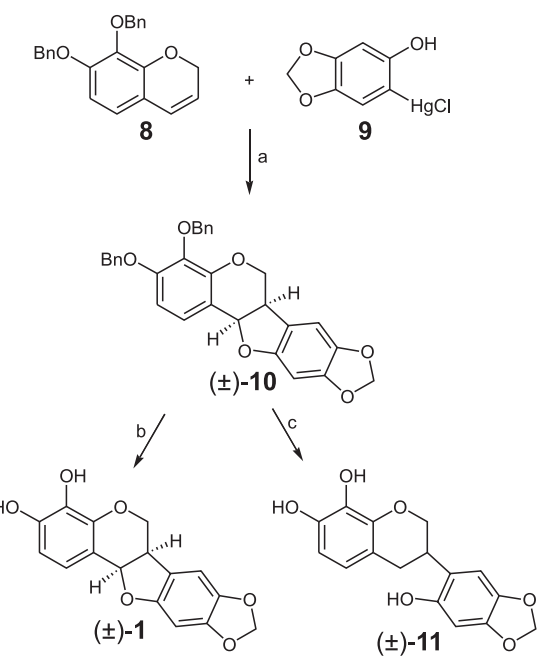

Scheme 2. Reagents and conditions: a) $\mathrm{PdCl}_{2} / \mathrm{LiCl}$, acetone, 55\%; b) $\mathrm{H}_{2}, \mathrm{Pd}-\mathrm{C}(10 \% \mathrm{~m} / \mathrm{m}), 3$ atm, acetone, $100 \%$; c) $\mathrm{H}_{2}, \mathrm{Pd}-\mathrm{C}$ (excess), 3 atm, acetone, $60 \%$.

Oxidation of the 3,4-di-O-benzyl-pterocarpan $\mathbf{1 0}$ with DDQ in THF at room temperature for $4 \mathrm{~h}$ led to the intermediate 3,4-di-O-benzylated coumestan 12, which precipitated out of the solution, and was collected by filtration. The presence of the conjugated system in $\mathbf{1 2}$ was clearly showed by the batochromic shift observed in the UV spectrum. ${ }^{11}$ The synthesis of coumestan $\mathbf{1 3}$ was acomplished by hydrogenolysis of the protecting benzyl groups in $\mathbf{1 2}$ ( Scheme 3).

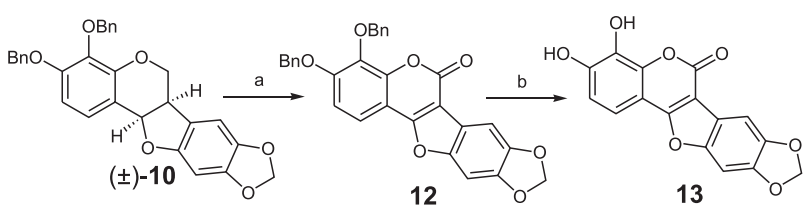

Scheme 3. Reagents and conditions: a) DDQ $2 \mathrm{mmol}$ in THF; rt; b) $\mathrm{H}_{2}$, Pd-C $(10 \% \mathrm{~m} / \mathrm{m}), 3$ atm, acetone, $70 \%$.

In summary, we have, for the first time, prepared natural pterocarpan $\mathbf{1}$ and its derivatives $\mathbf{1 1}$ and $\mathbf{1 3}$ in good overall yields. These compounds will be evaluated as antitumoral agents.

\section{Experimental}

General

Melting points were measured with a Fisher-Johns (Fisher Scientific Co) apparatus. Flash chromatography was performed using Merck silica gel 60, 230-400 mesh and Merck silica 60F 254 sheets. ${ }^{1} \mathrm{H}$ NMR and ${ }^{13} \mathrm{C}$ NMR were recorded on a Varian Gemini-200 instrument.

cis-(土)-3,4-di-O-benzyl-Pterocarpan (10)

To a mixture of $\mathrm{PdCl}_{2}(87 \mathrm{mg}, 0.49 \mathrm{mmol})$ and $\mathrm{LiCl}$ (42 $\mathrm{mg}, 1.0 \mathrm{mmol})$ in acetone $(5 \mathrm{~mL})$ was added chromen 8 $(158 \mathrm{mg}, 0.46 \mathrm{mmols})$ in acetone $(10 \mathrm{~mL})$. This mixture was stirred for $15 \mathrm{~min}$ at $0{ }^{\circ} \mathrm{C}$ and then 2-chloromercurio4,5-methylenedioxyphenol (172 $\mathrm{mg}, 0.42 \mathrm{mmol})$ in acetone $(10 \mathrm{~mL})$ was added. The suspension thus obtained was stirred for $12 \mathrm{~h}$ at $25^{\circ} \mathrm{C}$. After this time, brine $(150 \mathrm{~mL})$ was added to it and the mixture was extracted with acetyl acetate $(3 \times 50 \mathrm{~mL})$, the organic extract dried $\left(\mathrm{Na}_{2} \mathrm{SO}_{4}\right)$, and submitted to column chromatography to give the compound as a solid (128.6 mg, $56 \%)$, mp. $170{ }^{\circ} \mathrm{C}$.

${ }^{1} \mathrm{H} \mathrm{NMR}\left(\mathrm{CDCl}_{3}\right)(200 \mathrm{MHz}) \delta 7.38(10 \mathrm{H}, \mathrm{m},) ; 7.18(1 \mathrm{H}$, d, $J 8.6 \mathrm{~Hz}) ; 6.7(1 \mathrm{H}, \mathrm{d}, J 8.6 \mathrm{~Hz}) ; 6.7(1 \mathrm{H}, \mathrm{s}) ; 6.42(1 \mathrm{H}, \mathrm{s})$; $5.9(2 \mathrm{H}, 2 \mathrm{~s}) ; 5.48(1 \mathrm{H}, \mathrm{d}, J 6.3 \mathrm{~Hz}) ; 5.1(4 \mathrm{H}, 2 \mathrm{~s}) ; 4.3(1 \mathrm{H}, \mathrm{dd}$, $J$ 6.0, $3.6 \mathrm{~Hz}) ; 3.6(2 \mathrm{H}, \mathrm{m}) .{ }^{13} \mathrm{C} \mathrm{NMR} \mathrm{CDCl}{ }_{3}(200 \mathrm{MHz}) \delta$ $39.92(\mathrm{CH}) ; 66.39\left(\mathrm{CH}_{2}\right) ; 70.87\left(\mathrm{CH}_{2}\right) ; 75.00\left(\mathrm{CH}_{2}\right) ; 78.33$ $(\mathrm{CH}) ; 93.55(\mathrm{CH}) ; 101.07\left(\mathrm{CH}_{2}\right) ; 104.59(\mathrm{CH}) ; 107.81(\mathrm{CH})$; $114.26(\mathrm{C}) ; 117.65(\mathrm{C}) ; 125.36(\mathrm{CH}) ; 126-130(10 \mathrm{CH})$; 136.73 (C); 137.43 (2 C); 141.52 (C);147.88 (C); 149.74 (C); 152.72 (C); 153.94 (C). LRMS (EI) $m / z 480\left(\mathrm{M}^{+}\right), 389$, 91(base). IR (KBr) $v_{\text {max }} / \mathrm{cm}^{-1}: 3065$ - 3031 (aromatic H), 1613 (aromatic ring). 
cis-( \pm )-3,4-Dihydroxy-8,9-methylenedioxypterocarpan (1)

3,4-di-O-benzyl-pterocarpan 10 (31.8 mg, $0.07 \mathrm{mmol})$ in acetone was hydrogenated $(3 \mathrm{~atm})$ in the presence of Pd-C ( $10 \%$ by weight). After 30 min. the catalyst was filtered to give $(21.0 \mathrm{mg})$ in $100 \%$ yield. ${ }^{1} \mathrm{H}$ NMR $\left(\mathrm{CDCl}_{3}\right)(200$ MHz) $\delta 7.0(1 \mathrm{H}, \mathrm{d}, J 8.5 \mathrm{~Hz}) ; 6.73(1 \mathrm{H}, \mathrm{s}) ; 6.68(1 \mathrm{H}, \mathrm{d}, J 8.5$ $\mathrm{Hz}) ; 6.44(1 \mathrm{H}, \mathrm{s}) ; 5.92(2 \mathrm{H}, 2 \mathrm{~d}, J 5.12$ and $5.5 \mathrm{~Hz}) ; 5.5(1 \mathrm{H}$, d, $J 6.8 \mathrm{~Hz}) ; 4.32(1 \mathrm{H}, \mathrm{dd}, J 10.7$ and $4.8 \mathrm{~Hz}) ; 3.7(1 \mathrm{H}, \mathrm{t}, J$ $10.6 \mathrm{~Hz}) ; 3.57(1 \mathrm{H}, \mathrm{m}) .{ }^{13} \mathrm{C} \mathrm{NMR}\left(\mathrm{CD}_{3}\right)_{2} \mathrm{CO}(200 \mathrm{MHz}) \delta$ $41.14(\mathrm{CH}), 67.83\left(\mathrm{CH}_{2}\right), 79.53(\mathrm{CH}), 93.90(\mathrm{CH}), 102.05$ $\left(\mathrm{CH}_{2}\right), 105.87(\mathrm{CH}), 110.09(\mathrm{CH}), 113.52(\mathrm{C}), 119.31(\mathrm{C})$, $121.87(\mathrm{CH}), 133.72(\mathrm{C}), 142.38(\mathrm{C}), 145.22(\mathrm{C}), 146.71$ (C), 148,85 (C), 155,27 (C). LRMS (EI) $m / z 300\left(\mathrm{M}^{+}\right), 175$, 162(base), 150. IR (KBr) $v_{\max } / \mathrm{cm}^{-1}: 3513$ and $3442(\mathrm{OH})$, 3234-3031 (aromatic H), 1667 (aromatic ring). UV $\lambda_{\max } / \mathrm{nm}$ (MeOH): 310.

\section{3,4-Dihydroxy-8,9-Methylenedioxycoumestan (13)}

To a solution of $\mathbf{1 0}(44.1 \mathrm{mg}, 0.09 \mathrm{mmol})$ in THF (3.5 $\mathrm{mL}$ ) was added DDQ $(41.3 \mathrm{mg}, 0.18 \mathrm{mmol})$. The resulting mixture was stirred at room temperature for $12 \mathrm{~h}$. The intermediate 3,4-di-O-benzylated coumestan $\mathbf{1 2}$ precipitated out of solution and it was collected by filtration and washed with cold hexane. The crude product was allowed to react with hydrogen ( $2 \mathrm{~atm})$ in acetone for $6 \mathrm{~h}$. After this time the catalyst was filtred (CELITE) and concentrated in vacuo to furnish a amorphous solid $\mathbf{1 3}$ $(13.6 \mathrm{mg}, 54.5 \%) .{ }^{1} \mathrm{H}$ NMR $\delta 7.42(1 \mathrm{H}, \mathrm{d}, J 8.42 \mathrm{~Hz})$; $7.36(1 \mathrm{H}, \mathrm{s}) ; 7.34(1 \mathrm{H}, \mathrm{s}) ; 7.02(1 \mathrm{H}, \mathrm{d}, J$ 8.42); 6.16(2H, s). LRMS (EI, after derivatization with BSTFA $+1 \%$ trimethylchlorosilane $)^{12} \mathrm{~m} / \mathrm{z}, 456\left(\mathrm{M}^{+}\right)$, 441. IR ( $\left.\mathrm{KBr}\right)$ $v_{\max } / \mathrm{cm}^{-1}: 3435(\mathrm{OH}), 2921$ (aromatic $\left.\mathrm{H}\right), 1718(\mathrm{C}=\mathrm{O})$, 1632-1457 (aromatic ring). UV $\lambda_{\text {max }} / \mathrm{nm}(\mathrm{MeOH}): 348$.

\section{Electronic Supplementary Information}

${ }^{1} \mathrm{H}$ NMR, ${ }^{13} \mathrm{C}$ NMR and mass spectra for compounds $\mathbf{1}$ and $\mathbf{1 3}$ are available as PDF file at http://jbcs.sbq.org.br.

\section{Acknowledgements}

Our research was supported by grants from PRONEX (No. 41.96.0888.00), FAPERJ, FUJB-UFRJ and CAPES. A.J.M.S is a postdoctoral fellow of FAPERJ (No. 26/ 151.081/97) and C.B.N. of CAPES fellowships. Central Analítica NPPN-UFRJ for the analytical data.

\section{References}

1. Pezzuto, J. M.; Phytochemistry of Medicinal Plants, Plenum Press: New York, 1995.

2. Murray, A.; Hunt, T.; The Cell Cycle: An Introduction, Oxoford University: EUA, 1993 ; Weinberg, R. A.; Sci. Am. 1996, 275, 62.

3. Wall, M. E.; Wani, M. C.; Brown, D. M.; Fullas, F.; Huang, L.; Chaudhuri, S. K.; J. Nat. Prod. 1995, 58, 1966.

4. Gottlieb, O. R.; Sutheerland, I. O.; Ollis, W. D.; Cook, J. T.; Phytochemistry 1978, 17, 1419; Ohyama, M.; Tanaka, T.; Iinuma, M.; Jr., C. L. B.; Chem. Pharm. Bull. 1998, 46, 663.

5. Mcmurry, T. B. H. ; Martin E.; Phytochemistry 1972, 11, 3283.

6. da Silva, A. J. M.; Costa, P. R. R.; Aurelian, L.; Noel, F.; Buarque, C. D., Brito, F. V.; Souza, D. V.; Murakami, Y. L. B.; Melo, P. A.; Silva, N. M. V.; Caruso, R. R. B.; Castro, N. G.; Macedo, L. F.; Malkas, L.; Hichey, R.; Bioorg. Med. Chem. 2002, 10, 2731.

7. da Silva, A. J. M.; Costa, P. R. R.; Coelho, A. L.; Simas, A. B. C.; Tetrahedron Lett. 2001, 42, 4111; da Silva, A. J. M.; Costa, P. R. R.; Noel, F.; Buarque, C. D., Brito, F. V.; Souza, D. V.; Rodrigues, V. P.; Melo, P. A.; Silva, N. M. V.; Albuquerque, E. X.; Bioorg. Med. Chem. Lett. 2001, 11, 283; Costa, P. R. R.; Coelho, A. L.; Simas, A. B. C.; Synthesis 1999, 6, 1017; Lichtenfels, R. A.; Coelho, A. L.; Costa, P. R. R.; J. Chem. Soc., Perkin Trans. 1 1995, 7, 949; Coelho, A. L.; Vasconcellos, M. A. A.; Simas, A. B. C.; Rabi, J. A.; Costa, P. R. R.; Synthesis 1992, 10, 914 .

8. Breytenbach, J. C.; Rall, G. J. H.; J. Chem. Soc., Perkin Trans. 1 1980, 8, 1804.

9. Eisenbraun, E. J.; Vickery, E. H.; Pahler, L. F.; J. Org. Chem. 1979, 24, 4444.

10. Horino, H.; Ione, N.; J. Chem. Soc. Chem. Commun. 1976, 13,500 .

11. We have synthetized several pterocarpans and coumestans and in all cases a similar batochromic shift was observed (ref. 6). See also Spencer, R. R.; Bickoff, E. M.; Lundin, R. E.; Knuckles, B. E.; J. Agr. Food Chem. 1966, 14, 162.

12. Villamor J.L.; Bermejo A.M.; Tabernero M.J.; Fernandez P.; Analytical Lett. 2004, 37, 517.

Received: January 6, 2003 Published on the web: October 15, 2004 


\section{The First Synthesis of ( \pm )-3,4-Dihydroxy-8,9-methylenedioxypterocarpan, an Antitumoral} Agent and its Coumestan Derivative

Alcides J. M. da Silva, Chaquip D. Netto and Paulo R. R. Costa*

Núcleo de Pesquisas de Produtos Naturais, Centro de Ciências da Saúde, Bloco H, Universidade Federal do Rio de Janeiro, 21.941-590 Rio de Janeiro - RJ, Brazil
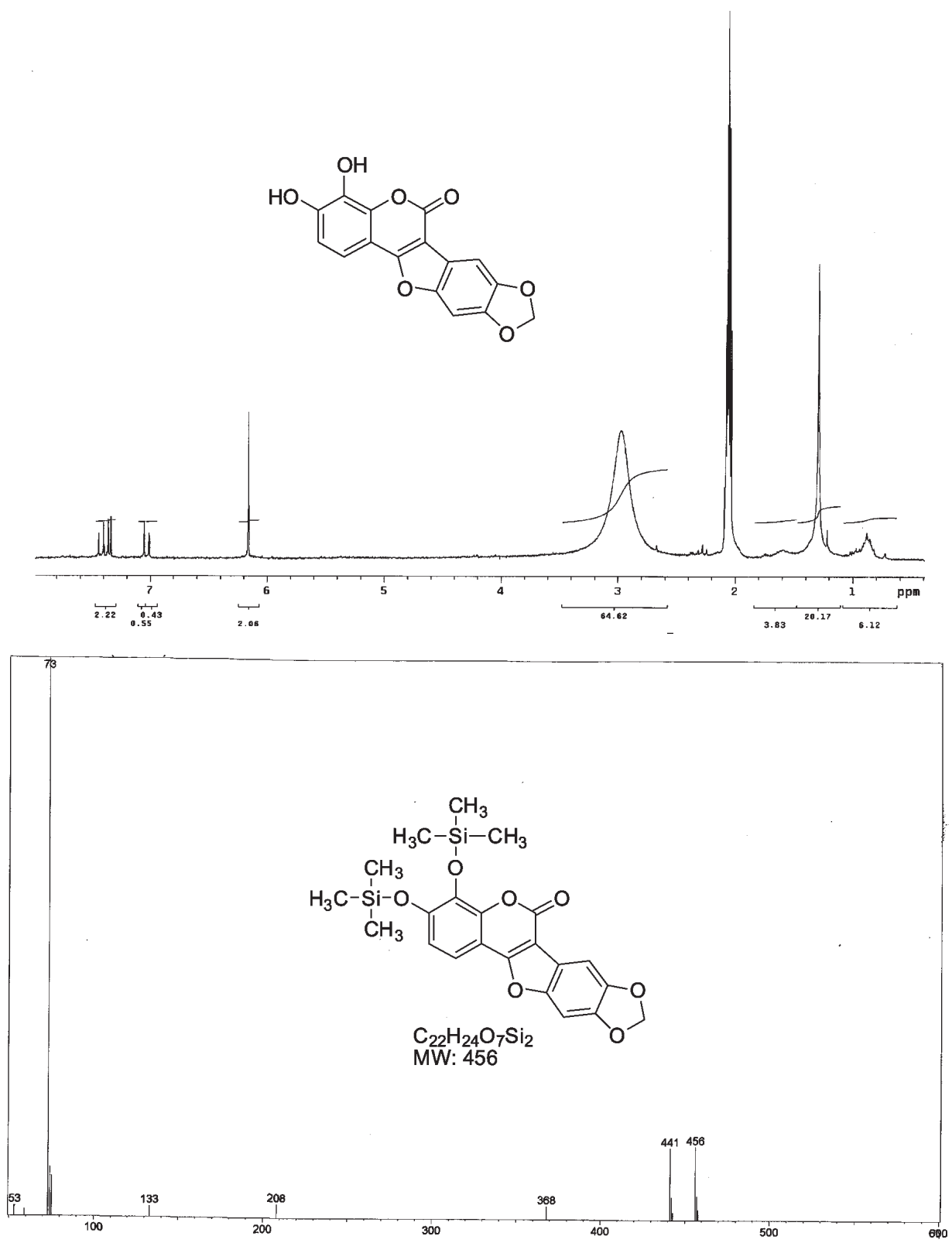

Figure 1. ${ }^{1} \mathrm{H}$ NMR and mass spectra for compound $\mathbf{1 3}$.

*e-mail: lqb@nppn.ufrj.br 

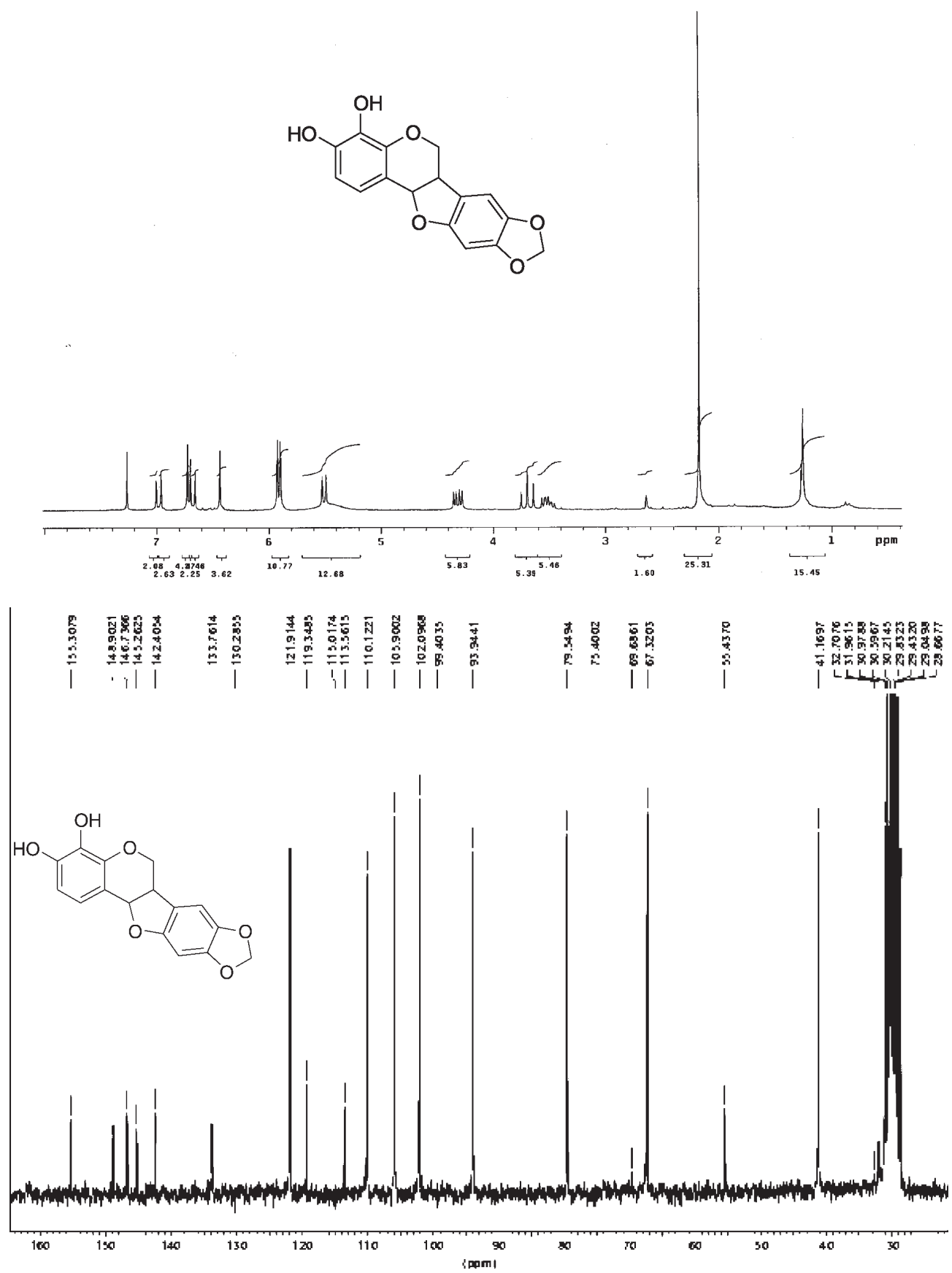

Figure 2. ${ }^{1} \mathrm{H}$ NMR and ${ }^{13} \mathrm{C}$ NMR for compound $\mathbf{1 .}$ 